\title{
Dual conditionality in welfare and housing for lone parents in Ireland: Change and continuity?
}

\author{
Mary Murphy
}

Social Sciences Institute, Maynooth University, Maynooth, Ireland

\section{Correspondence}

Mary Murphy, Social Sciences Institute, Maynooth University, County Kildare, Maynooth, Ireland.

Email: mary.p.murphy@nuim.ie

Funding information H2020 Horizon 2020 Research and Innovation Programme, Grant/Award Number: 649447

\begin{abstract}
This article focuses on multiple conditionalities in benefits and housing from the perspective of lone parents in Ireland. The Irish case echoes historical experiences elsewhere and is offered not as an exceptional or extreme case but as an in-depth single case study and a lens for comparison. Although contemporary forms and combinations of conditionalities are new to Ireland, the experience of multiple conditionalities in benefits and housing is not new. Hence, a historical perspective is used to examine contemporary multiple conditionalities in benefits and housing. In the past, conditional regimes for lone parents were justified in terms of moral reformation for first time mothers and avoiding moral contagion of mothers with subsequent pregnancies. In contemporary times, in the case of employment, lone parents are problematised as working part-time and "nesting" on in-work-benefits, and in the case of homelessness, lone parents who prioritise the security of tenure embedded in social housing are accused of "gaming" the system. While acknowledging ambiguities, the paper finds the overlap of welfare and housing discourses contribute, intentionally or unintentionally, to epistemological foundations or understandings of lone parents, shifting public perceptions, and framing them as "problems" to be solved. They simultaneously temper lone parents' expectations. Increased precarity and disempowerment is associated with dual conditionality, and ontological uncertainty is multiplied when experienced cumulatively across employment, social protection, and housing regimes in a context of generally
\end{abstract}


poor public services and labour market precarity and in the historical context of stigmatisation. Nonetheless, lone parents demonstrate considerable agency.

\section{KEYWORDS}

dual conditionality, housing, Ireland, lone parents, ontological insecurity, welfare conditionality

\section{1 | INTRODUCTION}

This article links two domains of policy (housing and social security), places them in historical context, and uses contemporary examples from Ireland to convey the complex, lived experiences of lone parents struggling with "two" related conditionality regimes. Accounts of poverty underestimate the degree to which housing, social security, employment, and childcare policies intersect in complex ways in lone parents' lives (Lewis, Land, \& Kiernan, 1997, p. 210). Ireland has been described as a laggard or late moderniser in relation to activation and welfare conditionality but, from 2010, shifted to a more active and conditional regime that includes a focus on changing expectations and behaviours of lone parents. Since 2012, a work-first activation policy Pathways to Work (Department of Social Protection [DSP], 2012) requires some lone parents to seek and accept full-time employment. From 2014, in the context of a new phenomenon of family and lone parent homelessness, families experience pressure to change expectations about the desirability of life-long social housing and to adapt their behaviour to source insecure private sector accommodation and cope with living in congregated emergency accommodation.

Assessment of historical and contemporary debate concerning conditionality in income support and housing regimes draws attention to underlying policy rationales and change and continuity concerning conditional interventions in Ireland. The Irish case echoes historical and contemporary experiences elsewhere (Thane, 2011) and is offered not as an exceptional or extreme case but as an in-depth single case study or a lens that can be used for comparative purposes. While appearing an outlier who has come late to welfare conditionality for lone parents, an historical lens shows Ireland enacted harsh forms of both employment and housing conditionality for lone parents, representing a degree of continuity with historical institutional conditional regimes for lone parents (Thane, 2011), but also clear differences. The paper probes where and how contemporary social security and housing polices intersect and how they practically and ontologically impact on lone parents in Ireland. The discussion reflects a deepseated ambiguity concerning lone parents in Ireland. A compassionate and caring paternalism still protects lone parents in Ireland from the worse excesses of Anglo Saxon welfare conditionality. However, lone parents experience greater conditionality and moral discourse than partnered mothers who are welfare claimants, and lone parents who deviate from policy expectations are publicly scorned.

Welfare conditionality for the purposes of this paper is understood as linking welfare rights, benefits, or services to "responsible" behaviour or particular obligations (Watts \& Fitzpatrick, 2018). Over time, internationally, lone parents have found themselves subject to an increasing range of welfare conditionality applied across a number of policy areas including employment, housing, and parenting (Finn \& Gloster, 2010). A range of literature questions the efficacy of employment-related welfare conditionality for lone parents (Haux, 2011; Johnsen, 2018), with little evidence that imposing welfare conditionality on lone parents achieves positive outcomes for women or children (Millar \& Crosse, 2017). Internationally, housing policy and practice has become a key site for conditionality (Watts \& Fitzpatrick, 2018, p. 67) with more use of conditional, probationary, and renewable social housing tenancies in the United Kingdom and shifts to segregated housing with conduct conditions in France, Austria, and Sweden. Johnsen, Fitzpatrick, and Watts (2014) explore "increasing expectations that homeless people engage with supportive 
interventions" and note lone parents' experience of housing-related conditionality and dual conditionality. Elsewhere, Healy and Finn (2017) explore how people experience intersecting welfare conditionalities.

The paper examines gendered knowledge underpinning recent policy. This draws attention to how underlying assumptions and rational economic frames of predominantly male and middle-class policy officials are erroneously applied to understand the reality of lone parents' employment and housing "choices" (Wright, 2012). In the past, conditional regimes for lone parents were justified in terms of moral reformation for first time mothers and avoiding moral contagion of mothers with subsequent pregnancies. In contemporary times, in the case of employment, lone parents are problematised as working part-time and "nesting" on in-work benefits, and in the case of homelessness, lone parents who prioritise the security of tenure embedded in social housing are accused of "gaming" the system.

The paper draws on policy documents and research examining lone parents' concerns about growing welfare conditionality in employment policy (Murphy, 2008, 2012) and secondary sources including policy evaluations and grey literature (Indecon, 2017; Society of St Vincent De Paul [SVP], 2019). In particular, the discussion is informed by a 2017 qualitative study with 10 homeless families who were accommodated in the first Family Hub, a new form of institutionalised congregated accommodation for homeless families (Hearne \& Murphy, 2017). This study, inspired by a new methodological concept, a Participatory Action Human Rights and Capability Approach, captured how the lived experience of lone parent families is impacted by a set of complex conditions around benefit receipt alongside an emerging behavioural conditionality in housing policy. The study involved multiple collective visits to the families accommodation that allowed a deeper engagement by the participants in the process of knowledge creation. In particular, it explored how living under dual conditionality impacted on capability and functioning to live a valued life. We proceed in Section 2 to theorise Irish welfare conditionality, placing it in an historical context, exploring its underlying rationales, and locating it in international terms. Section 3 focuses on recent conditional changes for lone parents in activation policy, whereas Section 4 explores new forms of behavioural conditionality in homelessness and social housing policy. The discussion in Section 5 reflects on the nature of gendered knowledge and assumptions underpinning recent policy and examines the underlying ambiguities concerning lone parents in Ireland. The conclusion celebrates gendered agency, micro and macro, historical and present.

\section{2 | A HISTORICAL PERSPECTIVE}

The Irish welfare state is difficult to theorise within comparative welfare state literature. A relatively weak case of a liberal welfare regime, it is often classed as a hybrid exhibiting some features reflecting a continental regime with underlying corporatist and catholic influences as well as familial features similar to Mediterranean regimes (Dukelow \& Considine, 2018; McCashin, 2019). We proceed with a brief chronological outline of how policy has related to lone parents with particular reference to its relevance to the theme of welfare conditionality. Table 1 highlights four key stages in the evolution of welfare provision for lone parents in Ireland. Prior to 1970, there was no formal income support, and welfare provision was through local discretionary provision, often in institutional settings with significant accommodation and employment conditionalities. From 1973 to 1990, welfare was provided through categorical payments with no work requirement. From 1990, we see a greater focus on employment and, from 2006 onwards, proposals for activation of lone parents. From 2011, we see the phased implementation of activation and work obligations for some, but not all, lone parents.

It is difficult historically to separate income and housing conditionality in the early history of the Irish welfare state, dominated as it was first by workhouses (Dukelow \& Considine, 2018) and the 1838 Poor Law condition of "less eligibility," and later, by Mother and Baby homes and Magdalene Laundries. Historically, church, state, and society collaborated to enforce strong income and housing conditionality by institutionalising women who fell outside narrow gender roles (Buckely, 2017). Unmarried mothers were considered a serious management and financial problem amidst fears that the Poor Law system was encouraging immorality (Luddy, 2011, p. 110). By the late 1920s, in the early days of the Irish state, unmarried mothers had become a symbol of unacceptable sexual activity in a rural, 
TABLE 1 Irish social security changes with particular impact on lone parents

\begin{tabular}{|c|c|c|}
\hline Date/Stage & Policy/legislation & Explanation \\
\hline 1923 (S1) & $\begin{array}{l}\text { Reform of the Poor Law to } \\
\text { Home Assistance }\end{array}$ & $\begin{array}{l}\text { Lone parents remain dependent on local stigmatised relief, often } \\
\text { institutionalised. }\end{array}$ \\
\hline 1923 (S1) & County Homes & County Homes replace work houses. \\
\hline 1935 (S1) & $\begin{array}{l}\text { Widows' and Orphans' } \\
\text { Pension }\end{array}$ & $\begin{array}{l}\text { First income support targeted at widows. Still "punitive } \\
\text { institutionalisation" of unmarried mothers. }\end{array}$ \\
\hline 1970 (S2) & $\begin{array}{l}\text { Deserted Wife's Allowance } \\
\text { (DWA) }\end{array}$ & $\begin{array}{l}\text { Right to provision if met criteria: older women with dependent child } \\
\text { means tested, and relatively onerous proof of desertion required. }\end{array}$ \\
\hline $1973(\mathrm{~S} 2)$ & $\begin{array}{l}\text { Deserted Wife's Benefit } \\
\text { (DWB) }\end{array}$ & Contributory (social insurance), otherwise as above. \\
\hline 1973 (S2) & $\begin{array}{l}\text { Unmarried Mother's } \\
\text { Allowance }\end{array}$ & $\begin{array}{l}\text { Conditions and means test based on the DWA, and the widows' } \\
\text { non-contributory pension. }\end{array}$ \\
\hline 1974 (S2) & Prisoner's Wife's Allowance & Based on the DWA. \\
\hline 1989 (S2) & $\begin{array}{l}\text { Deserted Husband's } \\
\text { Allowance }\end{array}$ & Based on the DWA, first payment aimed at men caring for children. \\
\hline $1990(\mathrm{~S} 2)$ & Lone Parent's Allowance & $\begin{array}{l}\text { No need to prove cause of lone parenthood, and open to both male } \\
\text { and female applicants. End of the term "unmarried mother." }\end{array}$ \\
\hline 1997 (S3) & One-Parent Family Payment & Parenting alone and means assessment are the core criteria to meet. \\
\hline 2006 (S3) & $\begin{array}{l}\text { Proposals for Supporting } \\
\text { Lone Parents (DSFA, 2006) }\end{array}$ & $\begin{array}{l}\text { Government discussion paper, proposed parental allowance and } \\
\text { recognition of part-time work-not implemented. }\end{array}$ \\
\hline 2011 (S4) & Single Working Age Payment & $\begin{array}{l}\text { Government discussion paper, proposed homogenisation of all } \\
\text { working age payments not implemented. }\end{array}$ \\
\hline 2012 (S4) & Changes to eligibility & OFP eligibility restricted to lone parents with youngest child under 7. \\
\hline 2012 (S4) & $\begin{array}{l}\text { Changes to earned income } \\
\text { disregards OFP }\end{array}$ & $\begin{array}{l}\text { Phased reduction of OFP earned income disregards to make uniform } \\
\text { with job seekers. }\end{array}$ \\
\hline 2014 (S4) & $\begin{array}{l}\text { Introduction of Job Seekers } \\
\text { Transition }\end{array}$ & $\begin{array}{l}\text { Halfway house payment for lone parents with youngest child under } 7 \text {, } \\
\text { requires activation but no employment obligation. }\end{array}$ \\
\hline $\begin{array}{l}2017-19 \\
(S 4)\end{array}$ & $\begin{array}{l}\text { Increases earned income } \\
\text { disregards }\end{array}$ & $\begin{array}{l}\text { Gradual restoration of earned income disregards for OFP and JST } \\
\text { recipients, maintenance anomalies restored. }\end{array}$ \\
\hline 2018 (S4) & $\begin{array}{l}\text { Low work intensity } \\
\text { households initiative }\end{array}$ & $\begin{array}{l}\text { Pilot voluntary activation programme for qualified adults } \\
\text { (spouses/partners of primary payment). }\end{array}$ \\
\hline
\end{tabular}

Source: Adapted from Spotlight No 1 2007, updated by author.

Abbreviations: JST, Job Seeker Transition; OFP, One-Parent Family Payment.

Bold is used to visually denote different stages.

patriarchal, and Catholic state with a morally conservative approach to welfare (McCullagh, 1991). Policy sought to discipline Irish social behaviour (Crowley \& Kitchin, 2008, p. 335) and intervene in the sexual lives of its citizens, limiting women and denying them full citizenship (Beaumont, 1997, p. 563). As elsewhere, including England and Wales (Thane, 2011), we see some nuance and ambiguous attitudes towards unmarried mothers with some concern for those considered "innocent or unfortunate" (Luddy, 2011, p. 112). By the 1930s, income support became available to (deserving) widowed mothers.

During the 1920s, a new institutional framework emerged, largely focused on minimising costs and the burden on taxpayers (Luddy, 2011, p. 114). Policy hierarchically classified women as ideal chaste virgins and married mothers, sexually deviant but redeemable first time unmarried mothers, and sexual transgressors (Inglis, 2002). A 1927 Commission for the Relief of the Sick and Destitute Poor recommended church run "Mother and Baby" homes for redeemable women and that intractable transgressors with multiple pregnancies be detained as long as necessary 
in punitive Magdalene Laundry (Luddy, 2011, p. 118). Children born in both types of institutions suffered very high mortality rates. Some families actively resisted attempts by church and state to institutionalise pregnant daughters and sisters or opted for County Homes over the punitive or harsh regimes of the Mother and Baby homes or Magdalene institutions (Luddy, 2011, p. 116; O'Sullivan \& O'Donnell, 2012, p. 7). Many pregnant women emigrated so that Pregnant from Ireland became a common signifier for British social services dealing with unmarried pregnant women fleeing Ireland. Nor was institutionalisation solely a case of state and church control. Rural society actively used coercive confinement and regulation of sexuality to manage out family members who threatened the stem-inheritance of family farms (O'Sullivan \& O'Donnell, 2012), whereas some urban families proactively used these systems to manage poverty. Prunty (2017) confirms government inquiry findings that later 20th century institutions sometimes provided support from caseworkers or social workers.

Postindependent Ireland was a theocratic state and deeply gendered. Article 41.2 of the 1937 Constitution celebrated the centrality of marriage, home, and motherhood in Irish women's lives, divorce was unconstitutional and abortion illegal. Extensive social change and modernisation throughout the 1960s and 1970s mirrored the second Vatican Council's focus on social justice, attitudes towards unmarried mothers softened somewhat (Luddy, 2011, p. 119), and Mother and Baby homes began to close. The 1967 U.K. Abortion Act also changed the context for Irish social policy, as did campaigns by the Irish Women's Movement for contraception and maternal support (Dukelow \& Considine, 2018). Following extensive engagement by antipoverty and women's lobby groups and a 1970 Commission on the Status of Women, a new Unmarried Mothers means tested allowance was introduced in 1973, opening up the possibility of independent life and the need for public housing. Reflecting the modification of the male breadwinner regime, in 1990, the Unmarried Mothers Allowance was renamed Lone Parents' Allowance, and by 1994, voluntary employment was encouraged through earned income disregards to compensate for expensive childcare. Over the 1990s and 2000s, a number of government reform proposals signalled a reorientation to employment, but this was alongside a constitutional prerogative to reinforce marriage (McCashin, 2019, p. 159), promotion of family values, and the privileging of wifely labour. Care remained sourced from private or familial rather than public spheres. In 1997, the Lone Parents' Allowance was renamed the One-Parent Family Payment (OFP), earned income disregards were increased as was access to employment services. Employment remained fully voluntary.

\section{3 | CONTEMPORARY ACTIVATION}

Over the 1990s, many Organisation for Economic Cooperation and Development (OECD) countries began to apply conditionality to working-aged welfare claimants (OECD, 2011). Ireland remained an outlier in comparative terms with, until 2012, no work obligations on lone parents; eligibility to income support lasting until the youngest child was aged 22 (if in full-time education); and the lowest pro rata investment in childcare (Finn \& Gloster, 2010; OECD, 2011). From the late 1990s, we see a shift from paternal to employment-oriented policy as championed by an influential OCED (2003, p. 23) report Babies and Bosses. The Irish government proposal "Supporting Lone Parents" (2006) proposed work conditionality for lone parents along with progressive supports for parenting (McCashin, 2019, p. 149). The 2008 economic crisis derailed prospects of social investment and individualisation but intensified calls for stricter activation and conditionality. From 2010, under OECD guidance and Troika monitoring, Ireland shifted to a fuller activation regime and merged benefit administration and employment services. More intensive engagement was combined with new penalties (amounting to $25 \%$ of the payment) for noncompliance with job seeking obligations and conduct conditions. Ireland is consistent with a turn to activation that includes market-led governance and individualization (targeting, tailoring, and one-to-one contracts or personal plans; Lødemel \& Moreira, 2014) but is considered, like Italy and Czech Republic, a slow moderniser (Van Berkel, de Graaf, \& Sirovatka, 2012). Overall, Finn (2019) observes a relative "lightness" in the implementation of this conditional regime, which Cousins (2019, p. 38) describes as "modest." 
In 2010, government also proposed a Single Working Age Payment, incorporating all working age adults into a job seeker regime (McCashin, 2019, p. 152). This was heavily resisted in the absence of investment in childcare and services. Nonetheless, partially driven by the short-term need for fiscal savings, the 2011 work-first activation regime, Pathways to Work (DSP, 2012) aligned generous OFP-earned income disregards with those of Job Seekers Allowance (JSA). ${ }^{1}$ Budget 2012 structural reforms also changed the eligibility criteria for OFP to make payment dependent on the age thresholds of the youngest child. Original proposals to shift all OFP recipients with a youngest child aged 7+ to a job seeker status were strongly resisted by a Seven is Too Young campaign led by the One Parent Exchange Network (OPEN, 2013). This led to a partial roll back in 2013 whereby those with a youngest child aged 7-13 could access alternative payments including a new and less conditional payment Job Seeker Transition (JST), which, while obliging participation in pre-employment services, education, or training, does not oblige paid employment. Lone parents with a youngest child aged 14 or older now rely on alternative payments, with those reliant on JSA obliged to seek and accept full-time employment. Even though lone parents in Ireland pay $40 \%$ of their income for childcare (the highest in the OECD), there are no alleviations or exemptions from the obligation to seek full-time work (Murphy, 2012). Government, by pursuing full-time conditionality without investment in childcare and education, was "putting the cart before the horse" (Millar \& Crosse, 2017).

Depending on the age of their youngest child in 2019, lone parents in Ireland now access a range of social welfare payments including OFP, JST, and JSA as well as carers and disability payments, whereas others were combining lowpaid employment and an in-work benefit, Working Family Payment. Lone parents on JST and JSA are subjected to a range of penalties for failure to comply with activation conditions (attend interviews, take up activation, education, or training), and, in the case of JSA, for not accepting a job offer or additional hours of employment. The reforms were introduced during a period of recession and high unemployment, in the absence of good quality affordable childcare, and with little recognition of additional practical and financial challenges of parenting alone. There are no disaggregated data to monitor sanction rates for lone parents. However, incidences have occurred (Finn, 2019), and lone parents feel threatened and fearful of sanctions (Zappone, 2016) and experience considerable confusion and frustration in the context of such change (One Family, 2015). The restructuring led to an increased likelihood of poverty and deprivation for many lone parent families (Indecon, 2017), with, in 2017, 84\% of lone parents in Ireland unable to meet unexpected expenses (highest of all EU-28 countries) and 30\% in great difficulty making ends meet (compared to an EU-15 average of 19\%; SVP, 2019).

The reform abolished features of the OFP that support lone parents to take up part-time employment. This decline in financial work incentives for those working part-time meant recipients in paid employment were financially worse off (Ireland, 2018), whereas in-work benefits were inaccessible for lone parents in precarious employment (Millar \& Crosse, 2018). Lone parent's incidence of in-work poverty rose from $8.9 \%$ in 2012 to $20.8 \%$ in 2017 compared with 4.2\% for two-parent families (SVP, 2019). The reduction in support for part-time work is informed by assessments that lone parents were rationally "nesting," and analysis of transition traps and "rational" monetary assessments suggested lone parents were overincentivised to work part-time leading them to "nest" on a combination of OFP, the in-work benefit Working Family Payment and part-time work. Lone parents, however, highlighted the difficulty of paying the high-cost childcare and overcoming loss of other welfare supports while working in a lowpaid labour market. Their input reflects a gendered moral rationality, which seeks an optimal balance between parenting, childcare, and labour market participation (Murphy, 2012).

\section{HOUSING CONDITONALITY}

To better understand the linkage between dual conditionalities in housing and social security, we now examine how lone parents can be differentially impacted by housing policy (Hearne \& Murphy, 2017). Inspired by Lewis et al.'s (1997) comprehensive assessment of lone parents and 20th century housing policy in the United Kingdom, this section more modestly sketches key features of the dualist market-dominated Irish housing system, particularly as it 
relates to lone parents. Table 2 outlines key stages and four elements of a segmented housing sector: local authority, housing associations, private rented, and owner occupied. Norris (2016, p. 1) describes how Ireland's welfare state as built on "a system of state-subsidised property redistribution" ... "intended to support a rural, familist social order," while the male breadwinner family was a key symbol in the ideology of Irish society (McCullagh, 1991). The first stage of Irish state policy focused on a significant public building programme of social housing by local authorities; from 1923 to the present day, the state built 365,350 houses and flats ( $22.2 \%$ of total Irish housing stock). From the 1930s, various tenant purchase schemes reduced this stock to 138,462 social housing tenancies in 2016 (accounting for half of all low-income subsidised tenancies). During Stage 1, many lone parents remained in family homes or lived in conditional regimes in County Homes, Mother and Baby homes, and Magdalene Laundries. These provided unmarried mothers relief from destitution but in a punitive form of coercive confinement (O'Sullivan \& O'Donnell, 2012, p. 2), with institutionalised social control (Dukelow \& Considine, 2018, p. 32). Over the 1960s and 1970s, many such

TAB LE 2 Evolution of Irish social housing changes with particular impact on lone parents

\begin{tabular}{|c|c|c|}
\hline Date/stage & Policy/legislation & Explanation \\
\hline 1838 (S1) & Poor Relief (Ireland) Act & $\begin{array}{l}\text { Indoor relief workhouse-institutionalisation of unmarried } \\
\text { mothers and their children. }\end{array}$ \\
\hline 1847 (S1) & Poor Relief Extension Act & $\begin{array}{l}\text { Outdoor relief for specific categories-only widows with two } \\
\text { legitimate children. }\end{array}$ \\
\hline 1927 (S1) & $\begin{array}{l}\text { Commission for the Relief of } \\
\text { the Sick and Destitute Poor }\end{array}$ & $\begin{array}{l}\text { A new institutional framework emerged to replace poor law } \\
\text { workhouses, mother, and baby homes for redeemable first time } \\
\text { unmarried mothers and Magdalene Laundries for more } \\
\text { challenging sexual transgressors. }\end{array}$ \\
\hline $1932(\mathrm{~S} 2)$ & $\begin{array}{l}\text { Expansion of public rental } \\
\text { housing sector }\end{array}$ & $\begin{array}{l}\text { New state invests in public rental housing sector }(345,000 \text { built } \\
\text { from } 1932 \text { to 2016). }\end{array}$ \\
\hline 1932 (S2) & Tenant purchase scheme & $\begin{array}{l}\text { Tenant purchase first introduced for rural tenants, then expanded } \\
\text { to urban tenants, generous conditions. }\end{array}$ \\
\hline
\end{tabular}

\begin{tabular}{|c|c|c|}
\hline 1966 (S2) & Housing Act & Consolidates housing legislation. \\
\hline 1977 (S3) & Rent Supplement (RS) & $\begin{array}{l}\text { First private rental income subsidy in Ireland (income support } \\
\text { focused). }\end{array}$ \\
\hline $1988(\mathrm{~S} 3)$ & Housing Act & Legislative consolidation of social housing policy. \\
\hline 2004 (S3) & Residential Tenancies Act & $\begin{array}{l}\text { Reform of residential landlord and tenant law in the mainstream } \\
\text { private rented sector. }\end{array}$ \\
\hline
\end{tabular}

\begin{tabular}{|c|c|c|}
\hline 2001 (S3) & Rental Assistance Subsidy & $\begin{array}{l}\text { First private rental income subsidy in Ireland (Housing Support } \\
\text { administered by Local Authority). }\end{array}$ \\
\hline 2011 (S4) & Social Housing Strategy 2020 & Signals shift to private rental sector. \\
\hline 2014 (S4) & $\begin{array}{l}\text { Introduction of Housing } \\
\text { Assistance Payment }\end{array}$ & $\begin{array}{l}\text { New private rental income subsidy in Ireland (housing support } \\
\text { administered by Local Authority. }\end{array}$ \\
\hline 2016 (S4) & $\begin{array}{l}\text { Social Housing Strategy } 2020 \\
\text { and Rebuilding Ireland }\end{array}$ & $\begin{array}{l}\text { Formal government social housing policy-shift to private sector. } \\
\text { Five pillars-gender blind and shift to private sector. }\end{array}$ \\
\hline 2017 (S4) & Family Hubs & $\begin{array}{l}\text { First Family Hub opened-new congregated living with strict } \\
\text { conditions and restricted rehousing options. }\end{array}$ \\
\hline $\begin{array}{l}2017-2018 \\
\quad(S 4)\end{array}$ & Social housing allocation & Tightening of social housing rules, restricting choice, and refusals \\
\hline $\begin{array}{l}2018-2019 \\
\quad(S 4)\end{array}$ & Private rental sector regulation & $\begin{array}{l}\text { Marginal improvement in security of tenure in response to } \\
\text { campaigns stressing the inadequacy of the private market as a } \\
\text { provider of secure housing. }\end{array}$ \\
\hline
\end{tabular}

Source: Compiled by author. 
institutions closed, and the 1973 Unmarried Mothers Allowance to some degree enabled lone parents live independently if they could access housing.

Reflecting a growing reliance on the private sector to meet social housing need, a second stage of social housing can be identified from 1974 when Rent Supplement was introduced as income support for those, including lone parents, without full-time employment and dependant on (unaffordable) private rental accommodation. The third stage in 2004 saw a significant shift with a Rental Accommodation Scheme to provide long-term social housing through the private housing rental market. The final crisis stage from 2008 includes a collapse of social housing provision and a housing supply crisis and as shift towards marketisation of housing.

In the final stage, we see how austerity almost halted investment in building social housing as public funding fell by $94 \%$ between 2008 and 2013 (Norris \& Hayden, 2018). The private rental sector became the primary site of provision of long-term social housing through, from 2014, the Housing Assistance Payment (HAP)-a means tested subsidy available to both employed and unemployed private rental tenants. Signalling an important shift in rights, this transfers responsibility for accessing social housing from the state to the person in need of housing. Rebuilding Ireland (Department of Housing, Planning and Local Government, 2016), the government's housing strategy, targets the private rental market to be the primary source for $85 \%$ of new social housing tenancies. New tax incentives encourage large-scale buy-to-let institutional landlords and global investors in the private rental sector.

From 2014 cuts to social housing budgets and over-reliance on a poorly functioning private sector lead to a significant rise in family homelessness. Lack of overall supply and private sector rent increases means poorer households unable to compete found themselves structurally excluded from increasingly unaffordable private rental housing. The lack of long-term, secure tenure means poorer household were vulnerable to landlords ending tenancies to pursue higher rental yields offered in a more competitive market. Loss of previous private rental accommodation remains primary cause of increased family homelessness (Long, Sheridan, Gambi, \& Hoey, 2019). Homeless families are housed in inadequate short-term emergency accommodation in guest houses and hotels, often in conditions highly inappropriate for children. By 2019, numbers of homeless exceed to 10,250, including almost 1,700 families with 3,749 children (Focus Ireland, 2017) and including a disproportionate percentage of migrant, Traveller and Black African families, and larger families. Although the scale and composition of homelessness depends on often contested definitions and measurements, a conservative but well-established assessment shows lone parents comprise $65 \%$ of homeless families (Focus Ireland, 2017), compared with $24 \%$ of families in the overall population (Hearne \& Murphy, 2017). Notably, unlike the United Kingdom, women in domestic violence refuges are not included in the formal assessment of homelessness (Lewis et al., 1997, p. 226).

Benefit conditionality and the housing cuts are directly linked as part of a wider austerity programme that impacted most on women with children and cumulatively left lone parents very vulnerable to the highest risks of poverty and deprivation (Ireland, 2018; SVP, 2019; TASC, 2016). Lone parents see their social and economic vulnerability directly translated into a disproportionate risk of housing poverty. Forty-five percent of lone parents report a heavy financial burden due to housing costs compared with $30 \%$ of two-parent families. The proportion of lone parents in arrears on their rent or mortgage repayments was $18 \%$ in 2017 , compared with $8 \%$ of other households with children (SVP, 2019). Some lone parents directly link labour market conditionality rules with their increased risk of homelessness leading Focus Ireland (2017) to recommend further study to better understand if and how the rule could trigger homelessness.

A key but ad hoc response to family homelessness emerged in 2017 when government, under pressure to deal with the serious problems associated with the highly inappropriate housing of children in private hotels without relevant child protection safeguards, began to invest in Family Hubs, congregated living spaces where each family has one bedroom and shares cooking, laundry, bathroom, and social spaces. Hubs have been developed by refurbishing existing buildings and accommodation including institutions, offices, guest houses, and warehouses. ${ }^{2}$ By late 2018 , 26 Family Hubs operated nationally with a total capacity for over 600 families, with more planned over the next 3 years. There is no time limit on the length of time families spend in these settings. Rules in the Family Hubs apply new forms of behavioural conditionality including curfews, visitor bans, physical restrictions on movement, parenting 
instructions, and obligations to search for private sector housing (Hearne \& Murphy, 2017). Long stays in such institutions run the risk of "therapeutic incarceration" (Gerstel, Cynthia, Bogard, McConnell, \& Schwartz, 1986). In two qualitative assessments of life in a Family Hub (Hearne \& Murphy, 2017; Ombudsman for Children's, 2019), both parents and children describe how "prison-like" environments impact on mental health and well-being and undermine residents' capability for choice and independent functioning.

I feel my parenting is checked all the time ... I got a warning ... it feels like an institution instead of a home ... our parenting is questioned in front of our children ... they are taking the parenting role off the parent ... when someone speaks down to you like this, you feel you are on the bottom. (various parents, cited in Hearne \& Murphy, 2017)

New conditional policies also restrict rehousing options for families seeking to exit emergency accommodation. A "Homeless HAP" provides prospective homeless tenants with extra subsidies to enable them compete for rental properties and so be "responsible" for sourcing accommodation to exit emergency accommodation. Mirroring the principle of "less eligibility" (Lewis et al., 1997, p. 6), policy makers believe families in dire circumstances will be more motivated to find housing solutions;

If you really need somewhere to live you will be highly motivated to find somewhere ... and you will keep putting in effort until you do. The local authority official behind a desk is not as motivated. (policy maker, cited in Hearne \& Murphy, 2017)

Families resist the insecurity of tenure associated with the HAP-supported private rental sector:

I do not want to keep moving my daughter around all the time ... and then I'm afraid that I will end back up in the homeless services again after my lease is up ... I would take HAP if I was guaranteed to be able to stay in the accommodation for a five year lease or whatever, and that I would be guaranteed somewhere else after that lease was up ... once it's not back to the homeless services. I will not keep putting my daughter through the same situation-it's not fair on her. (Emilia, lone parent cited in Hearne \& Murphy, 2017)

Support workers affirm a gendered moral rationality that leads parents to resist the insecurity of HAP-supported private rental accommodation and wait for more secure public housing:

Security for families? No HAP does not give it. If they are looking for social housing they know they are getting to have a long-term tenancy and that is their long-term goal-if they take HAP it's one year or two years-one year goes by very quickly. It's huge, especially when you have children, the security. Families are saying to us they want a minimum of five or ten years' security-an obvious thing you need. (Key Worker, cited in Hearne \& Murphy, 2017)

Long et al. (2019, p. 3) find that two thirds of families are reluctant "to enter the private rented sector due to a perceived insecurity of this tenure and/or negative experience in rental accommodation" but that nonetheless three quarters of families are extensively seeking private rental. Despite this, the statutory Dublin Regional Homeless Executive (DRHE, 2018, p. 13) are concerned that families in emergency accommodation "have a strong preference for a local authority tenancy and are generally not willing to consider HAP." In echoes of the past where unmarried mothers "chose" County Homes over Mother and Baby homes, some homeless families "choose" extended stays in Family Hubs over insecurity in the private rental sector. In response, the state attempts to change expectations, impose conditions, and play the "blame game." Family Hub accommodation is constructed around a conditional "licence" where the tenant must "agree" to work over a 6-month period to do all they can to seek and accept HAP- 
funded private rental sector accommodation. Resource workers support families through the behavioural and cultural changes needed to adapt and enhance their private rental sector house search. By late 2018, support workers reported what Dwyer (2004) described as "creeping conditionality" in the form of increasing statutory pressure to push homeless families towards utilising HAP. Over 2017-2018, a series of rule changes altered the choice architecture to diminish the range of public housing choices available to prospective tenants. The local authority can restrict choice and impose "reasonable" offers to those on a public housing waiting list who may be demonstrating "HAP reluctance." In June 2018, the statutory Homeless Inter-Agency Group (2018, p. 18) argued "it also needs to be considered whether it is appropriate for the State to provide emergency accommodation to households who are unwilling to consider HAP." This policy is presently applied for those in transitional housing projects (Holland, 2018).

Families opting to wait for public housing find themselves the focus of national blame games where homelessness is reconstructed, not as a problem of housing supply, but one of demand (Murphy, 2008; Wright, 2012). Examples of such "gaming" families are usually anecdotal accounts of complex family situations. However, over time, such myths become "evidence." Families refusing to alter their expectation of lifetime security of tenure are accused of "refusing reasonable offers," "wanting too much," and "having too much choice." The chairperson of the National Housing Agency reported to the Parliamentary Housing Committee (Ireland, 2017) that many families are "gaming the system," and the CEO of Dublin City Council described compassionate homeless services as "a magnet" (Keegan, 2019). As Lewis et al. (1997, p. 11) observe, such arguments underestimate "alternative value systems that give priority to emotional satisfaction and care," they also neglect the psychosocial impact of insecure housing associated with insecurity and lack of capacity to plan and control life (Hearne \& Murphy, 2017). The two separate aspects of housing conditionality overlap; behavioural controls in the day-to-day life in emergency accommodation and Family Hubs intertwine with wider and more implicit forms of conditionality within the overall architecture of housing supports. HAP is pushed as the only option for social housing, and by implication, support for emergency accommodation is conditional on the families accepting private sector housing. This layering of conditionality produces ontological uncertainty while failing to address the underlying structural issue of lack of affordable accommodation, both in the public and private sectors (Lewis et al., 1997, p. 238).

\section{5 | DISCUSSION}

We proceed by discussing four perspectives to deepen understanding of welfare and housing conditionality as applied to lone parents in Ireland: paternalistic social teaching, the male breadwinner state, gendered knowledge and assumptions, and the level of ambiguity in a policy and political discourse that reinforces ontological insecurity for lone parents.

Strong Catholic social teaching intertwined contractually with the paternalistic state to frame social policy in the Irish state. Church and state together pioneered harsh forms of employment and housing conditionality in Mother and Baby homes and Magdalene Laundries. After forced adoption, incarcerated in institutions, some women were coerced, under the strongest imaginable form of welfare conditionality, to live and work in harsh institutions. Institutional responses to homelessness persisted long after other historical forms of institutional social controls have, with the exception of prisons, been largely abolished or reformed (O'Sullivan \& O'Donnell, 2012). Infantilisation of women remains a contemporary feature of institutional Irish responses to female homelessness (Mayock \& Bretherton, 2017). There is a historical continuity in the choice to construct new coliving institutional arrangements for homeless families, $65 \%$ of whom are lone parents, in a regime delivered in some instances by paternalistic charities. Indeed, the first Family Hub opened in 2017 in High Park, Drumcondra, the site of a former Magdalene Laundry.

A constitutionally informed welfare model underpins Irish social policy. As in the United Kingdom, government sought to encourage a particular family form (Lewis et al., 1997, p. 277). A strong male breadwinner welfare model and traditional notions of dependency are "tenaciously embedded in policy maker's minds" and reinforced by constitutional protections (McCashin, 2019, p. 161). From the beginning, housing policy was framed in familistic terms 
(Norris, 2016), whereas income support for lone parents, introduced in 1973, was framed in a paternalistic paradigm and originally devoid of labour market ambition for lone mothers. While shifting from the outlier it was, Ireland still remains somewhat a laggard and protects lone parents in Ireland from the worse excesses of welfare conditionality (Cousins, 2019). However, underlying breadwinner path dependencies remain and account for the different levels of conditionality applied to lone parents and partners in welfare-reliant households, and this is despite considerable modernisation and attitudinal shifts towards married maternal employment. Full-time labour market conditionality is considered acceptable for lone parents but not married or cohabitating mothers with more capacity to work in paid employment (McCashin, 2019; Millar \& Crosse, 2017; Murphy, 2008, 2012). It seems lone parents are still not fully compatible with a society caught between "the tides of liberal individualism and a traditional authoritarian moral order" (Inglis, 2002, p. 16).

A third lens makes explicit the gendered knowledge informing policy and draws attention to the agency and underlying assumptions and motivations of predominantly male and middle-class policy officials (Wright, 2012). Historical treatment of unmarried mothers related not only to social morals but also to fiscal pressures (Luddy, 2011). Financial concerns about the ongoing cost of lone parent income support are a strong motivation informing welfare conditionality (McCashin, 2019). Similar to what Lewis et al. (1997, p. 278) describe as U.K. views of lone parents as "coldly rational and calculating," gendered assumptions of rational economic frames are used erroneously to understand the reality of lone parents' choices in relation to employment and housing and to justify a new "choice architecture" for vulnerable groups. Analysis focuses in the case of employment policy on problematising lone parents who, it is argued, work part-time and "nest" on state supports and in-work benefits. In the case of homelessness, policy makers problematise lone parents who prioritise secure public housing as "gaming" the system (see Fletcher, Flint, Batty, \& McNeill, 2016 for an extensive critique of this phenomena).

It is difficult to make sense of the motivation of more powerful upstream policy and political actors (Wright, 2012), to know if they appreciate constraints that structure choices (Lewis et al., 1997, p. 2), or to assess whether they may be cynically manipulating public perception. However, there is little doubt such discourses are important in framing shifts to more conditional welfare and social housing policy (Fletcher et al., 2016). Gaffney \& Millar, 2018, p. 6), examining parallel fraud discourse, demonstrate how welfare claimants are subjectified in formal policy documents as "rational skivers" or "calculative individuals who engage with the system cynically from the outset." The lone parent organisation One Family (2015) challenged media coverage of welfare fraud, requesting that "media and policy makers stop perpetuating notions of the deserving and undeserving poor" (cited in Gaffney \& Millar, 2018). In the mid-1990s, British lone parents were subjected to accusations of "queue jumping" social housing allocation lists and manipulating U.K. homelessness legislation (Lewis et al., 1997, p. 236; Wilson, 1994). Jacobs, Kemeny, and Manzi (2003) argue such rhetoric was part of a wider political economy agenda. O'Flynn, Monaghan, and Power (2014) argue likewise linking scapegoating of lone parents in relation to unfair housing allocation policies with wider austerity in Ireland, whereas Inglis (2002, p. 14) observes the tendency to scapegoat lone mothers in a time of social crisis.

A fourth lens highlights significant ambiguity in political, policy, and public discourse. Lone parents are constructed as problem families (Flanagan, 2018; Hearne \& Murphy, 2017), but this sits alongside narratives of "protecting the vulnerable" (SVP, 2019). Maternal framing resonates strongly with a society that values motherhood and believes not all citizens should have to work in paid employment. McCashin (2019, p. 242) draws on Rice (2015) to describe how Irish people value welfare as residual, believing people who can work should work, but that not everyone can or should work. Ambiguity towards lone parents is consistent with a residual and conservative regime, happy to apply conditions to a narrow range of claimants, and comfortable with discourse that values "people who get up in the morning" (Bardon, 2017), while in practice continuing to protect significant numbers of working-age welfare claimants from such conditionality. The new conditional welfare regime is described as modest (Cousins, 2019). Overall, the discourse appears more paternalistic than punitive in approach and more about engagement than coercion. In effect, there is little political appetite for sanctions for people with disabilities, partners of welfare claimants, and lone parents with primary school-aged children (McCashin, 2019). Watts (2013) locates Ireland's traditional 
approach to social housing rights as residual or needs based. Even though the social housing stock has declined and residual nature of social housing has intensified, only limited forms of conduct conditionality apply to Irish social tenancies that still infer strong life-long rights and, for local authority tenants, include both successor rights and the right to buy. This reinforces public housing as a more preferable option over insecure private rental options. Despite policy makers assertions, there remains little public support for making families homeless for failing to comply with conditional HAP search requirements.

However, despite such ambiguity, the various discourses contribute, intentionally or unintentionally, to epistemological foundations or understandings of lone parents, shifting public perceptions and framing them as "problems" to be solved. They simultaneously temper lone parents' expectations and reinforce their own ontological insecurity (Long et al., 2019). In effect, the intentional undermining of part-time employment, combined with new marketdriven housing policies, creates a sense of disorder and discontinuity regarding an individual's experiences and a disregard for work and life choices made in a context of gendered morality that informs work and care decisions. Making the link between ontological security and work and/or housing precarity (Nowicki, Brickell, \& Harris, 2019, p. 19) finds such changes deeply undermine self-identity, confidence, and empowerment, while increasing anxiety and insecurity and disempowerment (Bobek, Pembroke, \& Wickham, 2018; Padgett, 2007; Wright, 2012). Ontological uncertainty is multiplied when experienced cumulatively across employment, social protection, and housing regimes in a context of generally poor public services and labour market precarity. The policy system fails to understand how policies cumutively interact across housing, employment, care, and social security (Lewis et al., 1997, p. 279; Murphy, 2012). Ireland might practice a relatively light conditionality (Finn, 2019); however, the issue is less whether sanctions are applied, it is that threats of sanctions shift the ground for people and make them feel more vulnerable. Increased poverty and vulnerability translates into structural violence in mental health and poor well-being with the suicide rate of young women (including mothers) now similar to young men in some deprived areas (Kelly, 2018). Policy changes also reduce visibility of lone parents (Lewis et al., 1997, p. 5). The decline in numbers of OFP recipients from 87,840 in 2008 to 39,310 in 2017 (Department of Employment Affairs and Social Protection, 2018) reflects, not progress, but the restriction of the OFP to lone parents whose youngest child is aged under 7 . The social housing needs assessment (Housing Agency, 2018, p. 15) records that the number of OFP claimants in need of social housing reduced by nearly $25 \%$ in 2017 , reflecting the underlying restriction of eligibility to OFP. In the past, invisibility was a primary tactic in the incarceration of unmarried pregnant women. The contemporary tactic, in a policy environment where "what gets counted matters," is to make lone parents statistically invisible.

\section{6 | CONCLUSION}

Assumptions about idleness, moral contagion, and fears relating to escalating fiscal costs of unmarried mothers have persisted over four centuries. The "moral monopoly of the Catholic Church" and its hierarchy of motherhood eased with modernisation but is still evident in state policy. Constitutional provisions valuing marriage and a domestic role for women have a legal and political impact on policy (McCashin, 2019, p. 168). Care and compassion towards lone parents and their children combines with harder rhetoric that singles out lone parents and differentiates them from partnered mothers in receipt of welfare or at risk of poverty. Paternalism is evidenced in state and NGO perceptions and in how lone parents are problematized and offered solutions based on institutionalised congregated living.

We also see historical continuity and more optimistic assessments of individual and collective agency in the different patterns of agency of lone parents and their families of origin (Wright, 2012). Although some historically resisted "Mother and Baby homes" and Magdalene Laundries, some now resist the insecurity of precarious labour markets and the private rental housing sector and reject unfair conditions and unrealistic expectations (Finn, 2019). Many have found collective ways to articulate their perspectives and successfully campaign for change (One Family, 2015; OPEN, 2013; Zappone, 2016). In the case of employment policy, lone parent-led campaigns have had three considerable impacts, first shifting the age at which lone parents experience full labour market conditionality, second 
reversing cutbacks in OFP-earned income disregards, and third contributing to the introduction of a new affordable childcare scheme in 2016 (OPEN, 2013). However, over the same period, austerity deeply affected capacity for gendered mobilisation and caused some self-organised groups (including OPEN) to close, whereas other cuts weakened key agencies and feminist infrastructure. In social housing and homeless policy, we hear voices of lone parents in creative campaigns as they individually and collectively input into national and local media debate. Over 2017 and 2018 , we see more overt mobilisation about the housing crisis, with the National Women's Council of Ireland gendering housing campaign demands and homeless NGOs developing gendered policy capacity in dialogue with domestic violence organisations. Listening to the voices of lone parents, it is evident that, far from gaming or nesting, they have realistic ambitions for themselves and their children. Most lone parents want employment but realistically appraise their care obligations in the context of the limits of local precarious labour markets (McCashin, 2019; Murphy, 2012; SVP, 2019). Likewise, lone parents expressed the need for secure public housing located near social and family networks, which is informed by realistic assessments of what they need to advance their own and their children's wellbeing (Lewis et al., 1997). A gendered moral rationality (Duncan \& Edwards, 1999) provides an alternative lens to understand the motivations and behaviours of lone parents and to guide social policy towards more reasonable assumptions of what matters and works for lone parent families.

\section{ENDNOTES}

${ }^{1}$ Following a change of government in 2016, the cut was over time restored to 2012 levels.

2 These are not unlike the type of hostels that Margaret Thatcher advocated in the 1990s. It is notable that in the United Kingdom, the practice of accommodating families with children in BandB-type accommodation has been avoided (Lewis et al., 1997, p. 237)

\section{ORCID}

Mary Murphy (D) https://orcid.org/0000-0002-4020-3764

\section{REFERENCES}

Bardon, S. (2017). Varadkar wants to lead party for 'people who get up early in the morning'. Irish Times.

Beaumont, C. (1997). Women, citizenship and Catholicism in the Irish free state, 1922-1948. Women's History Review, 6(4), 563-585.

Bobek, A., Pembroke, S., \& Wickham, J. (2018). Living with uncertainty. Dublin: TASC.

Buckely, S. A. (2017). The cruelty man. Manchester: Manchester University Press.

Cousins, M. (2019). Welfare conditionality in the Republic of Ireland after the Great Recession. Journal of Social Security Law, 26(1), 30-41.

Crowley, U., \& Kitchin, R. (2008). Producing 'decent girls': Governmentality and the moral geographies of sexual conduct in Ireland (1922-1937). Gender, Place and Culture, 15(4), 355-372.

Department of Employment Affairs and Social Protection (2018). Annual Statistical Report 2017. Dublin: DEASP.

Department of Housing, Planning and Local Government (2016). Rebuilding Ireland. Dublin: DHPLG.

Department of Social Protection (2012). Pathways to Work 2012-16. Dublin: DSP.

DSFA. (2006). Proposals to Support Lone Parents, Dublin: DSFA.

Dublin Regional Housing Executive (2018). Report to department of housing, planning and local government. Dublin: DRHE.

Dukelow, F., \& Considine, M. (2018). Irish Social Policy: A critical introduction (Second ed.). Bristol: Policy Press.

Duncan, S., \& Edwards, R. (1999). Lone parents, paid work and gendered moral rationalities. Basingstoke: Palgrave Macmillan. 
Dwyer, P. (2004). Creeping conditionality in the UK: From welfare rights to conditional entitlements. Canadian Journal of Sociology, 29(2), 265-228.

Finn, D. and Gloster, R. (2010). Lone parent obligations: A review of recent evidence on the work related requirements within the benefit systems of different countries Report No 632, Sheffield: DWP.

Finn, P. (2019). Playing with the absurdity of welfare: The experiences of Irish welfare conditionality, Kildare: Maynooth University PhD Thesis.

Flanagan, K. (2018). 'Problem families' in public housing: Discourse, commentary and (dis)order. Housing Studies, 33(5), 684-707.

Fletcher, D. R., Flint, J., Batty, E., \& McNeill, J. (2016). Gamers or victims of the system? Welfare reform, cynical manipulation and vulnerability. Journal of Poverty and Social Justice, 24(2), 171-185.

Focus Ireland (2017). Lone parents and homelessness: Presentation to Oireachtas Joint Committee on Social Protection 12th January 2017. Dublin: Focus Ireland.

Gaffney, S., \& Millar, M. (2018). Rational skivers or desperate strivers? The problematisation of fraud in the Irish social protection system. Critical Social Policy, 1-20. https://doi.org/10.1177/0261018319834819

Gerstel, N., Cynthia, J., Bogard, J. F., McConnell, J., \& Schwartz, M. (1986). The therapeutic incarceration of homeless families. Social Service Review, 70(4), 543-572.

Haux, T. (2011). Activating lone parents: An evidence-based policy appraisal of welfare-to-work reform in Britain. Social Policy and Society, 11(1), 1-14.

Healy R. and Finn P. (2017). Methadone or my money: Competing governmentalities in the lives of unemployed drug service users ESPAnet Annual Conference Lisbon 14-16 ${ }^{\text {th }}$ September 2017.

Hearne, R., \& Murphy, M. P. (2017). Investing in the right to a home: Housing, HAPs and hubs. Kildare: Maynooth University.

Holland, K. (2018). Families in transitional housing face possibility of eviction, Irish Times, 5th Dec 2018.

Homelessness Inter-Agency Group (2018). Report to minister for housing, planning and local government. Dublin: DHPLG.

Housing Agency (2018). Summary of social housing assessment. Dublin: Housing Agency.

Indecon (2017). Independent review of the amendments to the one-parent family payment since January 2012. Dublin: DEASP.

Inglis, T. (2002). Sexual transgression and scapegoats: A case study from modern Ireland. Sexualities, 5(1), 5-24.

Ireland (2017). Houses of the Oireachtas report of the joint committee on social protection: The position of lone parents in Ireland. Dublin: Government of Ireland.

Ireland (2018). Houses of the Oireachtas Report of the joint committee on employment affairs and social protection: Labour activation. Dublin: Government of Ireland.

Jacobs, K., Kemeny, J., \& Manzi, T. (2003). Power, discursive space and institutional practices in the construction of housing problems. Housing Studies, 18(4), 429-446.

Johnsen, S. (2018). Conditionality briefing: Lone parents. UK: Welfare Conditionality Project.

Johnsen, S., Fitzpatrick, S., \& Watts, B. (2014). Conditionality briefing: Homelessness and 'street culture'. UK: Welfare Conditionality Project.

Keegan, O. (2019). Owen Keegan defends saying homeless numbers would drop if services cut Irish Times Monday Feb 18th https://www.irishtimes.com/news/ireland/irish-news/owen-keegan-defends-saying-homeless-numbers-would-drop-ifservices-cut-1.3797713 accessed March 20th 2019.

Kelly, B. (2018). Physical and mental health in post-recession Ireland: A community study from Tallaght, Dublin. Dublin: Meath Foundation.

Lewis, J., Land, H., \& Kiernan, K. (1997). Lone motherhood in the 20th century. Oxford: Clarendon Press.

Lødemel, I., \& Moreira, A. (2014). Activation or workfare? Governance and neo-liberal convergence. Oxford: Oxford University Press.

Long, A., Sheridan, S. Gambi, L., \& Hoey, D. (2019) Family homelessness in Dublin: Causes, housing histories, and finding a home. Dublin: Focus Ireland

Luddy, M. (2011). Unmarried mothers in Ireland 19930-1973. Women's History Review, 20(1), 109-126.

Mayock, P., \& Bretherton, J. (2017). Women's homelessness in Europe. Basingstoke: Palgrave MacMillan.

McCashin, A. (2019). Continuity and change in the welfare state: Social security in the Republic of Ireland. Basingstoke: Palgrave.

McCullagh, C. (1991). A tie that blinds: Family and ideology in Ireland. The Economic and Social Review, 22(3), $199-211$.

Millar, M., \& Crosse, R. (2017). Lone parents and activation, what works and why: A review of the international evidence in the Irish context. Galway: NUIG.

Millar, M., \& Crosse, R. (2018). Lone parent Activation in Ireland: Putting the cart before the horse? Social Policy and Administration, 52, (1), 111-129

Murphy, M. P. (2008). Reframing the Irish labour activation debate, safe guarding social rights and choices Policy Institute Blue Paper No 23, Dublin: TCD.

Murphy, M. P. (2012). Careless to careful activation: Making activation work for women. Dublin: National Women's Council of Ireland. 
Norris, M. (2016). Property, family and the Irish welfare state. Basingstoke: Palgrave Macmillan.

Norris, M., \& Hayden, A. (2018). An analysis of the financial sustainability of local authority provided social housing. Dublin: Community Foundation Ireland.

Nowicki, M., Brickell, K., \& Harris, E. (2019). Home at last: Life in Dublin's rapid build housing. Dublin: Dublin City Council.

OECD (2003). Babies and bosses. Paris: OCED.

OECD (2011). Doing better for families. Paris: OECD.

O'Flynn, M., Monaghan, L. F., \& Power, M. J. (2014). Scapegoating during a time of crisis: A critique of post-Celtic Tiger Ireland. Sociology, 48(5), 921-937.

Ombudsman for Children's (2019). No place like home: Children's views and experiences of living in Family Hubs. Dublin: Ombudsman for Children's Office.

One Family (2015). Why reform of the One Parent Family Payment is not working and One Family's solutions. Dublin: One Family.

OPEN (2013). Seven is too young. Open: Dublin.

O'Sullivan, E., \& O'Donnell, I. (2012). Patients, prisoners and penitents: Coercive confinement in Ireland. Manchester: Manchester University Press.

Padgett, D. (2007). There's no place like (a) home: Ontological security among persons with serious mental illness in the United States. Social Science and Medicine, 64(9), 1925-1936.

Prunty, J. (2017). The monasteries, Magdalen asylums and reformatory schools of Our Lady of Charity in Ireland, 1853-1973. Dublin: Columba Press.

Rice, D. (2015). Applying welfare regime ideal types in empirical analysis: The example of activation. In Z. Irving, M. Fenger, \& J. Hudson (Eds.), Social Policy Review 27: Analysis and debate in social policy. Bristol: Policy Press.

Society of St Vincent De Paul (2019). Working, parenting, struggling. Dublin: SVP.

Spotlight (2007). Lone parents in the social welfare system: issues and debates Dublin: Houses of the Oireachtas-Library and Research Service.

TASC (2016). Cherishing all equally. Dublin: TASC.

Thane, P. (2011). Unmarried motherhood in twentieth-century England. Women's History Review, 20(1), 11-29.

Van Berkel, H. H. A., de Graaf, W., \& Sirovatka, T. (2012). Governance of the activation policies in Europe: introduction. International Journal of Sociology and Social Policy, 32(5/6), 260-272.

Watts, B. (2013). Rights, needs and stigma: A comparison of homelessness policy in Scotland and Ireland. European Journal of Homelessness, 7(1), 41-68.

Watts, B., \& Fitzpatrick, S. (2018). Welfare conditionality. London: Routledge.

Wilson, W. (1994). Lone parents and housing research paper 94/11 18 January 1994 Education and Social Services Section House of Commons Library.

Wright, S. (2012). Welfare-to-work, agency and personal responsibility. Journal of Social Policy, 41, 309-328.

Zappone, K. (2016). Civic forum on lone parents. Dublin: Seanad Eireann.

How to cite this article: Murphy M. Dual conditionality in welfare and housing for lone parents in Ireland: Change and continuity? Soc Policy Admin. 2020;54:250-264. https://doi.org/10.1111/spol.12548 